\title{
When I Give, I Own: Building Literacy Through READ Community Libraries in Nepal
}

\section{Susan B. Neuman, Nafizuddin Khan, Thamsanqa Dondolo}

Efforts to create centers for literacy and social empowerment in rural areas of Nepal are beginning to bear fruit. Some of the improvements brought about by the community libraries are described here.

$\mathrm{T}$ he Rural Education and Development (READ) international nongovernmental organization (NGO) is working in the most remote areas in Nepal to build community libraries and fill them with rich resources of information and books. READ is revolutionizing the very definitions of library and outreach in communities that hunger for resources and greater empowerment by partnering with these communities to develop self-sustaining library community centers. In this article we provide an evaluation of READ and its pioneering approach to promoting information and literacy. We also describe how this model may effectively inform literacy efforts in the United States and throughout the world.

\section{Background}

Under the auspices of the International Reading Association, my colleagues and I (first author) were invited to conduct an evaluation of community libraries in Nepal. The evaluation was designed to examine evidence of READ's influence on the educational, social, and economic productivity in small communities at a time of rapid expansion for the READ organization, in Nepal as well as in other countries. Specifically, the project sought to further understandings of how community libraries, as storehouses of knowledge and information, might provide a vital and powerful resource for supporting literacy, social change, and social justice through empowerment in Nepal.

Despite progress in raising living standards in recent years, Nepal has remained one of the world's poorest countries (UNESCO Institute for Statistics, 2005). Although discrimination on the basis of caste has been illegal in Nepal since 1963 (Pande, 2004) discriminatory social practices persist in rural areas, along with restrictions on occupational mobility. Indigenous nationalities make up 37\% of Nepal's total population and speak more than 100 languages and dialects. Many of these peoples have been displaced from their traditional homelands, denied land rights, and subjected to heavy taxes through unpaid labor (Bhattachan, 2003). Illiteracy rates estimated by the UNESCO Institute for Statistics (2005) approach $25 \%$ of the total population ( 8 million). Gender inequitymore pronounced in the rural areas of the countryis profound, with only one quarter of all women even minimally literate (Pande, 2004).

READ began in 1991 in order to address these issues through the development of community libraries and community literacy. This type of "literacy in practice" (Singh, Acharya, \& Koirala, 2003) postulates that people are already learners and that what they need are locally relevant materials to facilitate new learning. Such an approach values the sets of practices and culturally determined literacies that already exist in a community (Barton \& Hamilton, 1998) and focuses on how these practices can be used to upgrade and generate resources that might ultimately reduce poverty. In this respect, community literacy is intimately tied to educational, social, and economic development (Pande, 2004).

READ was designed to create, advance, and leverage a replicable library-based model for sustainable economic development with the hope of diminishing 
the isolation, vulnerability, and marginality in which many Nepalese citizens live (Khati, 2003). Since its inception READ has partnered with 41 Nepali communities to develop self-sustaining library community centers.

\section{The READ Model}

For Nepal, a country whose population largely resides in villages outside a handful of urban centers, rural education and development are central to enhancing prosperity and advancement. Today, over $90 \%$ of the population is rural with many villagers isolated due to Nepal's geographic remoteness and its limited roads, electricity, and communications (Pande, 2004). Strengthening communications in these villages to promote greater awareness about education, health, sanitation, and human rights represents a key aspect of empowerment.

In the past, educators and social services have initiated campaigns or programs to improve basic education by providing resources and information services in the fight against illiteracy. For example, the National Education System Plan in Nepal attempted to use distance learning to improve adult literacy and help adults become more economically productive. Costs associated with upkeep eventually crippled the spirit of the initiative, leading to erratic and often inaccessible service (Khati, 2003). Cost factors have similarly limited the availability of general education in Nepal; government schools require fees from the children they serve, leaving many peasants in rural areas without any educational resources. International initiatives to revive and use libraries and information systems for literacy development have unfortunately not prevented the libraries' overall decline and deterioration.

In contrast to a traditional exogenous approach, the READ model is based on asset-building community development (Mathie, Polestico, \& Labitad, 2002). Drawing from both Vygotskian and neosociocultural perspectives, the model is based on the premise that people have "funds of knowledge" (Gonzalez, Moll, \& Amanti, 2005) and life experiences that can be harnessed for positive pedagogical actions. The model attempts to link people's ways of being in the world-their talking, thinking, acting, and valuing (Barton \& Hamilton, 1998)—in order to promote local literacy practices and enhance economic prosperity.
The model (Shrestha, 2005) places a high priority on collaborative efforts to increase economic productivity through income-generating activities that make the best use of the community's own resource base. The model builds on the following:

- Identifying and analyzing a community's past successes to strengthen people's confidence in their own capacities to take action

- Engaging people as citizens (rather than clients) in development and promoting empowerment and ownership

- Involving individual and community talents, skills, and assets (rather than focusing on problems and needs)

READ libraries function in the following way: Based on the needs of and demands from the community, READ provides initial financial support for the establishment of the library. But from the very outset the library is owned, managed, and run by the community in which it is placed. The community must contribute the land for the library and bear at least $20 \%$ of the initial costs. Further, each community is responsible for supporting the library with at least one sustainable income-generating project. These incomegenerating projects-depending on geographic location-include rental stores, fish ponds, printing presses, ambulances, and other services needed in the community. Income from these projects must meet the costs of staff, newspapers, book acquisitions, and book repair. The library and the sustainability projects, therefore, are used as developmental catalysts for many other initiatives in the community.

\section{Overview of the Evaluation Design}

Our purpose was to examine the impact of READ's unique model for improving literacy opportunities among children and adults and stimulating successful social entrepreneurship. Comprehensive communitybased initiatives (Neuman \& Celano, 2006) represent an important and promising opportunity to improve a broad array of educational, social, and economic outcomes in communities. At the same time, their very comprehensiveness and uniqueness in meeting the needs of individual communities have traditionally presented tremendous challenges to evaluators. 
Among the attributes that make such initiatives difficult to evaluate include the individual nature of communities, the range of community dynamics, the boundaries of the initiative, and the absence of appropriate controls for comparison purposes.

To address the complexity of community-based initiatives, evaluators have applied new strategies to provide evidence for evaluations (Connell, Kubisch, Schorr, \& Weiss, 1995). These strategies use multiple methods that individually may not be wholly satisfactory but that together may provide substantial markers of progress. Such methods might include conducting surveys, selective interviews, or focus-group discussions; establishing a community self-monitoring capacity; or employing visual ethnography techniques (photographs that highlight certain characteristics of an environment; Neuman, 1999). By triangulating data, evaluators can provide a more textured picture of what may be happening in these community settings to inspire confidence in the validity of the results.

For our first strategy in providing an overview of libraries and their services, we constructed surveys designed to give us background information on all community libraries supported by READ. One survey, targeted to the READ staff, focused on management issues including monitoring, accountability, and data management. Another survey examined the library practices in each community, including outreach activities, sustainability projects, and challenges or successes in maintaining library services. These data were returned and analyzed by the first author three weeks prior to our visit to Nepal.

From these initial data, it was clear that libraries and their services varied across several important criteria. For example, older, more established libraries reported more outreach activities than ones that were just getting started, villagers in rural areas seemed to use libraries as their single point of contact more than those in large marketplaces, remoteness versus ease of access appeared to affect levels of community involvement, and cultural differences and norms seemed to play an important role in the potential impact of these libraries. Consequently, our second strategy was to employ a purposive sample (Yin, 2003) to explicitly examine some of these differences.

Because the basic question of the evaluation was to address whether the activities consciously undertaken in these community-based initiatives provided greater literacy opportunities for children and adults- thereby influencing economic and social development-we established a series of comparisons. We sought situations that could allow us to compare libraries and communities. To better understand how community members used print resources, for example, we sought to examine how an older, more established library might compare with a library that was just getting started. We compared libraries in rural areas with more urban libraries near marketplaces. We also looked at caste status in each location. In each case, by comparing and contrasting situations we sought to compare how these libraries functionedessentially answering the following questions: How might these libraries differ? How might they appear alike? What might have happened in the absence of the library?

The in-depth analysis of libraries occurred over a three-week period in the autumn of 2006. Following arrival in Kathmandu the three evaluators met as a team with READ staff, conducting interviews and reviewing documents to examine the READ model. Together, we visited two libraries to refine our questioning strategies. Each member of the team was subsequently dispatched to a different region of the country to observe a total of four libraries, seeking to examine how each of these community-based resource centers influenced educational, social, and economic empowerment (see Table 1).

We independently and systematically examined the community context of each library, its management structure, sustaining projects, and outreach efforts in each community. Structured interviews were scheduled with the management team in each library, and focus groups were conducted with women, school leaders, and teachers in the immediate area. Photographs were taken at each site, highlighting the environmental features in the library. In addition, as time allowed, we visited villages, marketplaces, school libraries, and activities in the local community. Once these independent observations were completed, we returned to Kathmandu to review our observations, triangulate our findings, discuss any discordant events, and examine emerging themes in the data. These initial findings and tentative interpretations were presented to a representative group of the READ community for member checking to examine whether our findings were plausible. Based on the group's comments and questions, the results we reported were regarded as consistent and dependable (Merriam, 1998). 
Table 1

List of Libraries Visited

\begin{tabular}{|c|c|c|}
\hline Laxmi & Central Nepal & Urban, highly diverse \\
\hline Jhuwani & Southern Nepal & Tharu, low caste \\
\hline Argyole & South Central Nepal & Terai \\
\hline Rameshor & Southern Nepal & Semiurban \\
\hline Srijana & Southeastern Nepal & Poor, lower-caste \\
\hline Madumalai & Eastern zone & Mixed Terai culture \\
\hline Sangam & Southeastern Nepal & Brahmin, Newar \\
\hline Thak & North Central Nepal & Thakali, semiremote \\
\hline Puthang & North Central Nepal & Thakali, entrepreneurial \\
\hline Lekh Nath & Eastern Nepal & Brahmin, Newar \\
\hline Dholakha & North Central Nepal & Urban, diverse \\
\hline
\end{tabular}

Figure 1

A Nepali Classroom

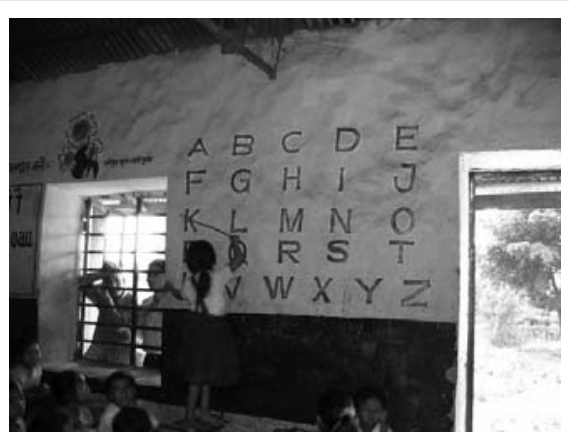

Photograph courtesy of the authors.

\section{What We Found}

Despite advances in recent years, children in rural areas in Nepal have limited opportunities for literacy learning. The current infrastructure for education is poor. School officials indicate that average class size can be as high as 80 students per class in the early grades and 60 students per class in the upper grades. Teacher training is minimal, with only 25 hours required for teacher preparation at all levels.

Schools suffer from a paucity of materials. Workbooks on various subjects shape the curriculum. Walls are bare, aside from the alphabet printed in Nepali and English in most classrooms (see Figure 1). School libraries are limited or nonexistent; literature books, if any, are often locked safely away in cabinets.

Promoting literacy to the indigenous people has represented a tremendous challenge. Understandably, due to poverty and unemployment, subsistence has taken precedence over education for many. During the planting and harvesting season, for example, children are likely to be absent more than two weeks in a month; temporary migrations due to employment in other areas may even extend these absences. Therefore, determining how to engage people in literacy activities that are meaningful, accessible, and tied to a community's most immediate and pressing needs represents a critical step in establishing a book culture for literacy development.

READ libraries are filling a critical gap, exerting a powerful influence on literacy activities and economic and social development in Nepal. Our experiences weave together a portrait of how literacy may be tied to prosperity, equity, and poverty reduction in developing countries.

\section{Creating Access to Literacy Materials}

As shown in Table 2, READ libraries provide books and other resources for communities that often have limited access to information. The libraries are open 12 hours per day, only closing during festivals, and generally contain rich resources of pamphlets, books, magazines, and materials for all ages.

Books are catalogued by color to denote subject, with adult and children's books shelved together in a range from easier to harder reading levels. The average number of books per library is about 3,500; however, this figure varies across communities. Laxmi library, for example, which all three evaluators visited, contained over 6,000 books. 
Table 2

Characteristics of READ Community Libraries

Current cost of a sustainable library

Total number of computers in READ libraries

Average number of books

Average number of villagers employed by READ library

Number of librarians trained since 1991

Toy libraries

Average hours open

Contributing members

\section{US $\$ 46,000$}

95

3,500

5

75

41

12 hours per day/

7 days a week

10,279 males

5,131 females
READ libraries, however, contain more than reading materials. Each library includes a dedicated children's section with books and a toy library filled with Montessori-like manipulatives (see Figure 2).

All libraries also include a computer room (with one or more computers), printers, photocopiers, occasional Internet access, and video and television for the community to watch movies and cartoons. Some libraries also have a room for meetings and special gatherings.

Extensive access to materials represents an important step toward helping the Nepalese people attain critical literacy skills. Yet perhaps even more extensive are the strategies that community members used to support reading development. Each library, for example, develops its own weekly "wall newspaper"-a newspaper with a bit of national news along with many contributions made by the local community (see Figure 3). Such easy access to local news helps the library to be seen as a community center for information.

\section{Outreach to the Community}

Involving the local community in library activities, however, is not left to chance. Through the use of strategies described as "participatory rural appraisal" (World Bank, 1994) to help identify the needs of the community, outreach becomes a vital activity of each library. Sita, a volunteer from Jhuwani's library, told us,

When we started the library, there were no women users. We thought about how to increase the participation of the library. We created a subcommittee and we called a meeting. No one came. I asked one woman
Figure 2

Children's Book Selection at the Jhuwani Library

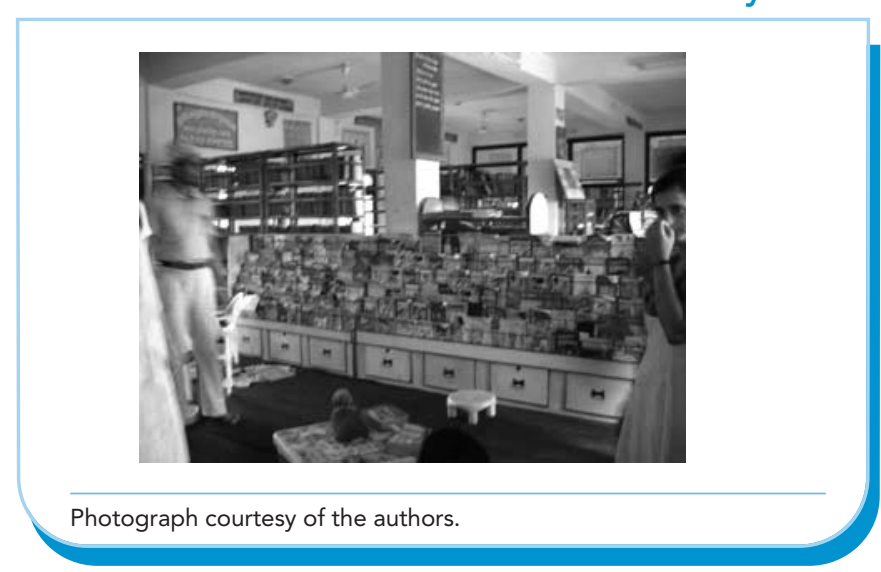

Figure 3

The Wall Newspaper

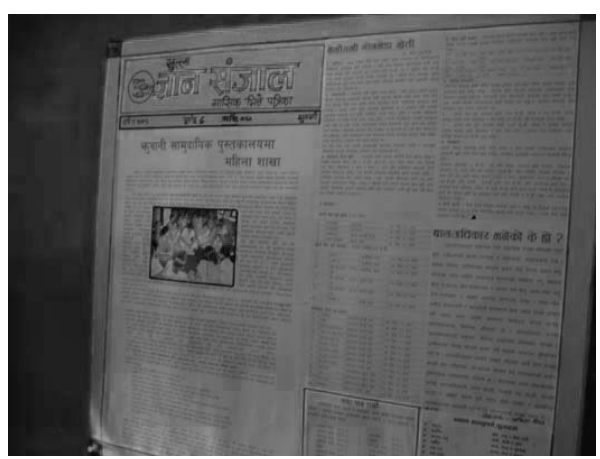

Photograph courtesy of the authors.

why she did not come, and she told me she couldn't write her name.

So we encouraged them-telling them it was not necessary to write or speak. We said-if you want, you can say something about your experience. We know you 
have a lot of experience about children. You can share. You can sing a song, or tell us a story. You have a lot of knowledge. This is your place.

They started to speak - they told us what happened in their home and, even people who could not express their name, they began to speak up. We were so encouraged. Slowly, and slowly, the women came, and when we announced that there was a leadership program, we had so many women we couldn't stop them.

Outreach activities like these-organized first by the local management committees, then taken on by active volunteers-recognized that literacy involvement often occurred through practical action. Although regarded as a key mechanism for social mobility and advancement, literacy attainment was seen as a long-term goal. More immediate goals were practical concerns. One member of the women's commission put it this way: "They see it as a source of information. If they have problems, they visit the library." In each of the libraries visited, we found the beginnings of a book culture developing through these outreach activities (see Table 3).

Some outreach activities were organized around specific issues like reproductive health or employment. In one library, for example, a room is dedicated to women's health. A doctor visits once a week and meets with women's groups on family-planning issues. But in some libraries the activities are more informal. Visiting at Argyole library, we heard one patron explain,

Table 3

READ Outreach Activities

The following are examples of the most prevalent outreach activities:

Community meetings

General health clinics

Women's health clinics

Blood drives

Investment and microfinancing training

Women's entrepreneurship training

English classes

Literacy classes

Animal livestock workshops

Women's discussion groups

Vaccination drives

Peace-building conferences

Leadership training

Book days

Wall newspaper training and production

Mothers' classes

AIDS awareness programs
We like to come and read books, watch TV, and listen to $\mathrm{AV}$ (videotapes) during our leisure time, which is about 12:00-2:00 each day. Together we talk about health issues and how to get coordinated, how to raise our goats. We talk about what to do when there is no doctor, and then we'll build a course around these issues.

According to READ program officers, mobilizing villagers in rural areas where cooperation is essential for existence has been more successful than in urban areas. When we visited a migrant family in a region with untouchables (the lowest caste of people), we found that the library is seen as a source of liberation. We interviewed a young woman living in a small home with 14 other family members and discovered that she was studying to be a health teacher. She wakes up every morning at 4:30, walks many miles to the local college, cooks for the family, and is the assistant secretary on the management team for the library. When we asked why she volunteers, she said simply, "Books are my passion." She and other untouchables are welcome in the library.

In such rural areas of poverty, school is often seen as a luxury. Because of the harvest and a family's many chores, one day one child may go to school, and the next day another child from the family will be given the opportunity. In 10 of the libraries, early childhood educational programs in addition to the toy libraries help to provide a basic safety net. Children come for half a day for classes that focus on health and cleanliness. They play with the toys, learn basic alphabet skills, read stories, and watch television cartoons. As one person put it, "Children used to play with mud and stone. Now they play with books and toys." According to the local school superintendent, these classes will constitute the only education for some children.

In the Jhuwani community, volunteers have established a kind of branch library for parents and children who must work in the fields all day. A person is chosen to act as a local librarian, considered a great honor, and selected books and toys are placed in his or her home for the neighbors' use.

The women gathered together and decided who would be the most appropriate person to have a mobile library. Who could lead us? Who should we give the responsibility to? The villagers selected a woman with great local knowledge, and when we visited her home we saw a little table on which there is a selection of books, and toys for children to play with. (Sita Adhikari, head of the Women's Cooperative at Jhuwani library) 
READ's libraries have benefited, as well, from collaborations with other NGOs. The Open Knowledge Network project, introduced in Nepal in 2005, runs in a number of READ-supported centers. Its mission further supports libraries as a knowledge source by disseminating knowledge that adds value to people's lives. In one community, we met a woman who identified a type of snail that proved to have medicinal value in curing a particular virus. She shared this information with the knowledge network. Similarly, another woman had read that a mother had died as a result of eating an excess amount of bitter nuts. She warned her community about it through the Open Knowledge Network.

From these and other experiences, we found that READ's participatory approach facilitated information sharing, analysis, and action among these key stakeholders. These advances have gone far in making the case for literacy improvement, demonstrating the important connections between literacy and empowerment.

\section{Literacy Development and Economic Productivity}

Observations and interviews indicated that READ libraries are improving the lives of villagers through sustainable economic empowerment activities (see Table 4 for examples). Moreover, the asset-based community library model appears to have had both direct and indirect effects on economic productivity in rural areas.

For example, the sustainability projects have brought different castes together in joint activity. In Lek Nath, the cell phone service went out, forcing the ambulance service-a project run by the Newars (a business caste) -into a crisis. One man in the community, a Tharu (an indigenous caste), had a land line and generously agreed to help the ambulance in its work for the community. "Day time, night time, all the time he does his duty," said one villager about the man, with great pride. With new respect from his community, the Tharu man continued to help until the situation got better.

Women are heavily involved in economic activity in Nepal, yet in the past have not benefited monetarily from their work. They take care of the household, work in the fields, and tend to the animals while their husbands seek employment, often in other countries.
Table 4

Sustainability Projects

\begin{tabular}{|lc|}
\hline Types of services & Number of libraries \\
\hline Telephone & 6 \\
Ambulance & 3 \\
Rickshaw & 1 \\
Saw mill & 1 \\
Printing press & 1 \\
Storefronts & 14 \\
Storeroom & 5 \\
Meeting hall & 4 \\
Catering & 3 \\
Machinery building & 1 \\
Loan & 5 \\
Fisheries/livestock & 2 \\
Souvenir shop & 1 \\
Tourist services & 1 \\
Total number & 48 \\
\hline
\end{tabular}

Fourteen-hour days are not unusual in the rural women's lives, and they are burdened by poverty and limited opportunities. READ libraries serve as information centers and have had some effects in breaking this negative cycle. As one member of the management team mentioned,

Who doesn't want a better life? But they have no way. What can they do without growing food? They have an interest in helping their children, but they have no money. We know their condition-we are citizens of this community. And we believe if we give them information, they can slowly lift up their life. Our interest is to improve their livelihood through economic activities. Without that, their living standard will not increase.

Perhaps the greatest stride in economic development has resulted from the savings and loan cooperatives emerging in each of the READ libraries. Using participatory rural appraisal strategies, these associations have had effects on empowering core groups of women. An example of this strategy is provided in the following explanation by one of the women:

\footnotetext{
We get women to sit in the round and discuss what they want to happen. They put stones and things down and say what they have on their mind-cultural practices, traditional practices. We discuss different kinds of businesses-we use a lot of tools.
}

Following discussions like these, women in villages served by READ have created savings and loan 
Figure 4

Decision Making in a Women's Savings and Loan Group

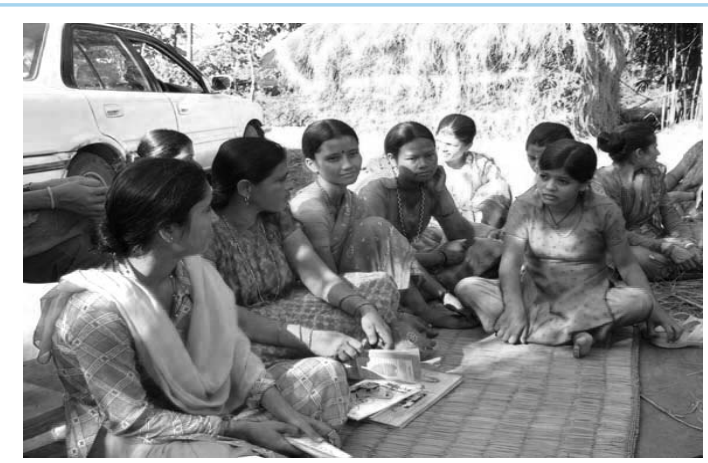

Photograph courtesy of the authors.

cooperatives (one library has 41 different groups) to help families through emergencies as well as raise capital for greater employment (see Figure 4). When we visited a meeting, we heard about the methods of one cooperative from the women involved:

We collect our savings and ask if anyone needs to take a loan. As a group we debate the terms of the loan and when and how the loan must be repaid. So the meeting begins by first pooling our money; then asking who needs money; and then deciding the loan period, the interest rate, and when the money must be returned.

We also talk about home and social affairs. One woman is pregnant, and we talk to her about what cereal to eat, how much fruit she must eat, how to measure. We show her books about it. Once, women used their thumbs to check out these books. Now they can write their names.

READ's contributions to economic empowerment and to the mobilization of marginalized groups are increasing efforts to break down disparities that currently exist among gender, caste, and indigenous groups. These efforts are likely to make critical contributions to the economic development of citizens in Nepal.

\section{Literacy and Social Development}

Social inequities continue to plague progress in Nepal. Continuing discrimination against indigenous groups, the low status of women, systems of patrilineal descent, and rules of inheritance have interacted to isolate and subordinate many of the citizens throughout the country (Singh et al., 2003). Poverty reduction and progress are ultimately tied to solving these social inequities. READ libraries sponsor programs that help people not only to become aware of these societal and cultural forces at work but also to better understand how to influence these dynamics.

Libraries have provided a focal point for meeting in the community to discuss common issues. They bring people together, not only through the sustainability projects but also with clubs. Women's clubs have emerged in all 41 libraries. Many want to learn about women's rights and the laws that pertain to them. One group, for example, has studied how to get a citizenry card, allowing its members to claim property, obtain a bank account, and become a part of an association. Further, women have taken on important leadership roles on management committees, as librarians, or as teachers-activities through which they have developed an important voice. Before the libraries, women had difficulty leaving home. Focusgroup discussions revealed that the libraries have become a legitimate destination for meetings. In fact, one woman reported that her guardian increasingly sends her to the library to get more information.

READ libraries have mobilized other community members as well. In each community, libraries have sponsored vocational educational programs including candle making, bee keeping, and creating crafts to sell in the tourist markets. In Srijana, the local beekeeper now makes a comfortable living and is coordinator of the agricultural section in the library (see Figure 5). Relationships like these have become engines for further community action. When we asked community members what their library's greatest success has been, for example, one older gentleman proudly said, "social unity. The library has built social unity and cooperative feeling."

Our observations suggested that the social unity that bonded people together resulted from communitydriven development. The president of the management group starting a new library told us this story:

We gathered our parents. We prayed to our God, which is our custom. And all of our parents put a stone in the middle of the circle. And later in a special ceremony, we collected a donation from each stone. Some people had only a penny, others only a handful of sand. But together we received more than 1,500 household donations to support our library.

Perhaps the most telling story of all, however, was that of a management committee member who said, 
"When I give, I own. My children have the right to use this library. If anything goes wrong, if anything is not working properly, let us plan together. All of us are stakeholders in this democracy."

\section{What Can We Learn From READ?}

READ libraries have a critical role in helping disadvantaged and marginalized groups use new opportunities to become better educated and economically and socially empowered. We believe there is much that can be learned from the READ model for programs in the United States, as well as in other highly industrialized nations.

First, the approach builds on a community's assets-its strengths, and not its deficits. There are no layers of bureaucracy. Rules are not imposed on people. Leadership teams are established by the people in the community. Leaders live in the community, understand it, and are ultimately accountable to their immediate constituency. When problems arise, community members and local leaders hold discussions, argue, and ultimately pose solutions that may benefit the entire community.

Because each community is unique, each library is distinctive in its response to serving the interests, needs, and purposes of its local citizenry. Libraries in agricultural areas become information centers for issues relating to livestock, farming, and water. Libraries in more urban areas use the local funds of knowledge (Gonzalez et al., 2005) to produce products that might create sustainable income streams. Similarly, book selections for each library are based on what is important to the community members. In this respect, the libraries are reflections of the communities in which they reside.

Second, as community resource centers libraries broadly define outreach to include activities that are important to the community. Outreach activities are not created for them; rather, the community members themselves make these decisions. They use their meeting spaces to provide health clinics, lectures on reproductive rights, or vocational classes specially targeted to the immediate needs of the community. Through their rich array of activities they are breaking down caste barriers and drawing in a diverse range of people who want to take advantage of their services. In every case, they are meeting people
Figure 5

Learning About Bee Keeping From the Library

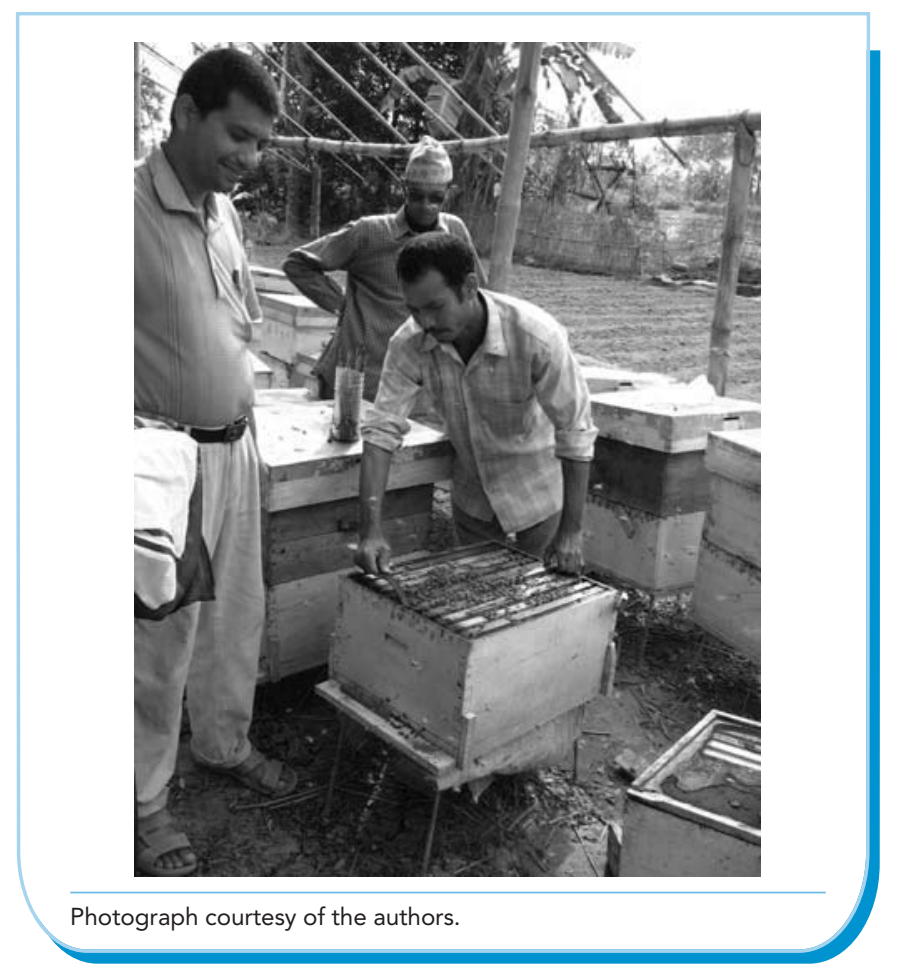

"where they are" to create new opportunities for learning and development.

And third, these libraries address literacy development not through formal training but by tying literacy activities to practical action. Literacy becomes a tool for knowledge generation to improve one's economic and social life. As a result, literacy is seen as having a functional and purposeful role in attaining goals.

Specifically, we summarize some of the best practices of the READ model as the following:

- There is open access to a broad constituency. Libraries are open 12 hours each day, 7 days a week.

- Books and outreach activities are related to community needs in the language of their patrons.

- Books and constructive toys create a center for early childhood education.

- Libraries are owned and operated by the community through sustainability projects that support economic and social development.

- Many opportunities are created for women and indigenous people to lead in their community and to participate in activities, helping them develop a voice and communicate with others. 
READ libraries have made tremendous strides in improving access to a wide range of information resources. Still, there is much work to be done. Administratively, for example, READ lacks data systems necessary to accurately track circulation and attendance figures. Consequently, quantitative analyses of the impact of libraries on literacy development, a crucial missing element, must await further analysis.

Further, READ needs to work with communities to build a greater infrastructure for their libraries. Librarians need better training to accurately catalogue materials. Many of the books currently indexed have been donated by outsiders and are unattractive, inaccessible (due to language), or outdated, taking up valuable space in the libraries. Finding resources in Nepali on topics that are of vital interest to the community would only enhance the connections between literacy and empowerment. Further, partnering with organizations to provide literacy training for adults and story hours for children, many of whom have had to drop out of school, would help to strengthen their reading and writing skills and create additional opportunities for work and greater social mobility.

READ community libraries have grown from 1 in 1991 to 41 in 2007 and have energized the Nepalese people in rural areas to engage in spirited dialogues about their own future educational, economic, and social development. It is a powerful model and an exportable one. Communities throughout the world can benefit from embracing this highly participatory approach to literacy and social and economic empowerment.

Note: We would like to thank Toni Neubauer of READ for her generous support of this project. We also sincerely appreciate the efforts of Jim Wile and Sakil Malik of the International Reading Association for their wise counsel and help with logistics. Finally, we are especially grateful to Sharad Shrestha and Sanjana Shrestha of READ in Nepal who provided a window into the world of the Nepalese people.
Neuman teaches at the University of Michigan, Ann Arbor, USA; e-mail sbneuman@umich.edu.Khan works at the Dhaka Ahsania Mission in Dhaka, Bangladesh; e-mail nafizuddinkhan@yahoo.com. Dondolo works at the South Africa Library for the Blind in Grahamstown; e-mail

tdondolo@msukaligwa.gov.za.

\section{References}

Barton, D., \& Hamilton, M. (1998). Local literacies: Reading and writing in one community. New York: Routledge.

Bhattachan, K.B. (2003). Indigenous nationalities \& minorities of Nepal. London: Minority Rights Group International. Retrieved October 29, 2007, from nipforum.org/bhattachan_report.pdf

Connell, J.P., Kubisch, A.C., Schorr, L.B., \& Weiss, C.H. (Eds.). (1995). New approaches to evaluating community initiatives: Concepts, methods, and contexts. Washington, DC: The Aspen Institute.

Gonzalez, N., Moll, L., \& Amanti, C. (Eds.). (2005). Funds of knowledge: Theorizing practices in households, communities, and classrooms. Mahwah, NJ: Erlbaum.

Khati, R.D. (2003). Education in dilemma: A Nepalese perspective. Kathmandu, Nepal: Udaya Books.

Mathie, A., Polestico, R., \& Labitad, L. (2002, February 21). Assetbased community development: An overview. Presentation at the Asset-based Community Development Workshop, Bangkok, Thailand.

Merriam, S.B. (1998). Qualitative research and case study applications in education. San Francisco: Jossey-Bass.

Neuman, S.B. (1999). Books make a difference: A study of access to literacy. Reading Research Quarterly, 34(3), 286-311.

Neuman, S.B., \& Celano, D. (2006). The knowledge gap: Implications of leveling the playing field for low-income and middle-income children. Reading Research Quarterly, 41(2), 176-201.

Pande, S.R. (2004). Nepal human development report 2004: Empowerment and poverty reduction. Kathmandu, Nepal: United Nations Development Programme. Retrieved October 29, 2007, from www.undp.org.np/publication/html/nhdr2004/

Shrestha, S. (2005). READ: Annual report 2005. Kathmandu, Nepal: READ.

Singh, S., Acharya, S., \& Koirala, B.N. (2003). Issues of literacy: A critical review and experience of women's literacy in Nepal. Kathmandu, Nepal: Didibahini.

UNESCO Institute for Statistics. (2005). UIS statistics in brief: Nepal. Montreal, QC: Author. Retrieved November 5, 2007, from stats .uis.unesco.org/unesco/TableViewer/document.aspx?ReportId $=124 \& I F \_$Language $=$eng\&BR_Country $=5240 \& B R \_$Region $=40535$

World Bank. (1994). The World Bank and participation. Washington, DC: Operations Policy Department, World Bank.

Yin, R. (2003). Case study research: Design and methods (3rd ed.). Thousand Oaks, CA: Sage. 